\title{
Berat Lahir dan Mortalitas Anak Sapi Belgian Blue dari Rumpun Resipien dan Ketinggian Tempat Berbeda
}

\section{(Birth Weight and Mortality of Belgian Blue Calves from Different Rec ipient Breeds and Altitude)}

\author{
Praharani L ${ }^{1}$, Sianturi RSG ${ }^{1}$, Kusumaningrum $\mathrm{DA}^{1}$, Parlindungan $\mathrm{O}^{2}$ \\ ${ }^{1}$ Balai Penelitian Ternak, PO Box 221, 16720 \\ ${ }^{2}$ Balai Embrio Ternak, Cipelang, 16004 \\ lisapraharani@pertanian.go.id
}

\begin{abstract}
The Belgian Blue cattle were imported to Indonesia for increasing beef production. A preliminary study was done to know the birth weight and pre-weaning mortality of BB calves from some recipient dam breed in different altitude. About 86 records of Belgian Blue purebred calves resulted from embrio transfer were used in this study. Data of birth weight were analysed using general linear model with recipient dam breed, altitude and sex of calf as fixed effect. Data of mortality were analysed using chi-square for different altitudeThe birth weight were significantly affected by recipient dam breed and altitude $(\mathrm{P}<0.05)$, but not sex of calves $(\mathrm{P}>0.05)$. Birth weights were $44.44 \pm 1.68 \mathrm{~kg}, 40.58 \pm 2.71 \mathrm{~kg}, 50.53 \pm 1.12 \mathrm{~kg}$, $50.85 \pm 1.62 \mathrm{~kg}$ and $55.56 \pm 1.21 \mathrm{~kg}$ for Brahman, Ongole grade, Simental, Limousine and Friesian Holstein (FH) recipient dam, respectively. The birth weights were $43.09 \pm 1.46 \mathrm{~kg}$, $51.11 \pm 0.92 \mathrm{~kg}$ and $54.18 \pm 1.29 \mathrm{~kg}$ for upland, middleland and lowland areas, respectively. The pre-weaning mortality were affected by altitude $(\mathrm{P}<0.05)$. The percentage of mortality were $61.1 \%, 22.3 \%$ and $41.9 \%$ for upland, middle land and lowland, respectively. The study concluded birth weight of BB purbred calves were highest in recipient dam of FH. BB calves performed better in middle land and above based on higher birth weight and lower mortality. This result was a preliminary study used as a recommendation in developing Belgian Blue cattle in Indonesia.
\end{abstract}

Key words: Altitude, recipient dam breed, birth weight, mortality, Belgian Blue calves

\begin{abstract}
ABSTRAK
Sapi Belgian Blue (BB) diimpor ke Indonesia untuk meningkatkan produksi daging sapi. Suatu penelitian awal dilakukan untuk mengetahui berat lahir anak sapi BB dan mortalitas pra-sapih anak sapi Belgian Blue dari beberapa rumpun induk resipien pada ketinggian tempat yang berbeda. Sebanyak 86 data kelahiran anak sapi Belgian Blue murni hasil transfer embrio digunakan dalam penelitan. Data berat lahir dianalisa menggunakan model linear umum dengan sumber keragaman rumpun induk resipien, ketinggian tempat dan sex anak. Mortalitas dianalisa menggunakan chi-square berdasarkan ketinggian tempat. Berat lahir anak sapi BB dipengaruhi oleh rumpun induk resipien dan ketinggian tempat $(\mathrm{P}<0,05)$, tetapi sex anak tidak signifikan $(\mathrm{P}>0,05)$. Berat lahir anak sapi BB berturut-turut 44,44 $\pm 1,68 \mathrm{~kg}, 39,58 \pm 2,71 \mathrm{~kg}$, $50,53 \pm 1,12 \mathrm{~kg}, 50,85 \pm 1,62 \mathrm{~kg}$ dan 55,56 $\pm 1,21 \mathrm{~kg}$ untuk rumpun induk resipien Brahman, Peranakan Ongole, Simental, Limosin dan Frisian Holstein (FH). Berat lahir untuk dataran

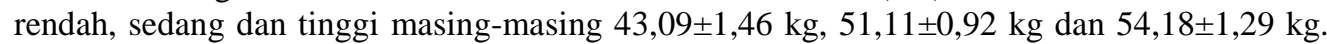
Mortalitas pra-sapih dipengaruhi oleh ketinggian tempat $(\mathrm{P}<0,05)$. Tingkat mortalitas berturut-turut $61,1 \%$, 22,3\% dan 41,9\% untuk dataran rendah, sedang dan tinggi. Penelitian
\end{abstract}


menyimpulkan berat lahir tertinggi anak sapi BB diperoleh dari rumpun induk resipien FH. Anak sapi BB hasil transfer embrio menampilkan performa lebih baik pada dataran sedang dan tinggi berdasarkan berat lahir dan mortalitas. Hasil penelitian ini bermanfaat sebagai rekomendasi bagi pengembangan sapi BB di Indonesia.

Kata kunci: Ketinggian tempat, rumpun induk resipien, berat lahir, mortalitas, anak sapi Belgian Blue

\section{PENDAHULUAN}

Sapi Belgian Blue (BB) dikenal memiliki karakteristik spesifik yaitu otot hipertropi, dimana terdapat penyembulan otot pada bagian pundak, punggung dan bagian paha belakang. Sapi BB termasuk salah satu rumpun sapi yang memiliki fenotipe double muscling (DM) yang ditunjukkan dengan perototan yang besar (Fiems \& Ampe 2014). Fenotipe DM disebabkan oleh terjadinya mutasi secara alami gen myostatin yang mengkode MTSN protein yang berfungsi mengatur pertumbuhan otot (Cieploch et al. 2017). Kejadian mutasi gen myostatin mengakibatkan terjadinya muscular hypertrophy (MH) atau otot hipertropi dibandingkan dengan sapi non-double muscling (Fiems 2012). Batubara (2017) menyimpulkan bahwa sifat hipertropi yang diturunkan melalui pejantan dapat dimanfaatkan untuk meningkatkan fenotipe ternak penghasil daging yang lebih produktif dan efisien.

Fenotipe DM dari sapi BB ini memberikan keuntungan seperti pengingkatan perototan yang menyebabkan peningkatan jumlah karkas, persentase daging, menurunnya masa tulang dan pertumbuhan badan yang lebih cepat sehingga menghasilkan berat badan yang besar (Mota et al. 2017). Selain itu sapi DM memiliki kualitas daging yang baik seperti rendah lemak, rasio PUFA:SFA yang tinggi, konversi asam lemak omega-3 yang tinggi dan kandungan protein yang lebih tinggi dibandingkan sapi non-DM (Sevane et al. 2014).

Disamping keunggulannya, Cieploch et al. (2017) dan Bouyer et al. (2014) melaporkan kelemahan sapi DM antara lain kaki bagian kecil (tidak proporsional dengan besar tubuh), tulang patah dan lemah, sindrom klinis (penyakit pernapasan, urolithiasis, alveolar hypoxia, hypoxemia) dan dystocia. Menurut Kolkman et al. (2010) sebanyak 9095\% kelahiran anak sapi BB melalui operasi Caesar baik anak yang berasal dari induk sapi BB murni dengan kawin alam atau melalui transfer embrio disebabkan oleh berat lahir yang besar dan bentuk tulang pinggul anak yang lebih besar sehingga mengalami kesulitan beranak alami (Kolkman et al. 2012).

Sapi BB yang berasal dari Belgia ini sudah tersebar hampir di seluruh dunia untuk dimanfaaatkan dalam program persilangan dengan tujuan meningkatkan berat badan dan perototan sapi lokal (Bittante et al. 2018). Indonesia mendatangkan sapi BB dalam bentuk semen beku dan embrio beku dalam rangka meningkatkan produksi daging dalam negeri, (Ditjen PKH 2017). Introduksi semen beku sapi BB lebih digunakan untuk tujuan persilangan melalui Inseminasi Buatan (IB) dengan rumpun induk akseptor yang berbeda. Sedangkan embrio beku melalui Transfer Embrio (TE) dilakukan pada induk resipien dengan rumpun yang berbeda yang selanjutnya dapat digunakan sebagai sumber material genetik sapi BB untuk produksi sapi BB murni. Keberadaan sapi BB akan memperkaya keragaman sapi potong, meskipun dalam pengembangannya perlu dipertimbangkan kelayakan secara ekonomi maupun biologi (Widyas et al. 2018).

Keberlangsung pemeliharaan embrio sejak awal implantasi berkaitan dengan lingkungan uterus dan corpus luteum resipien. Mekanisme hubungan antara resipien dan embrio dalam program TE disebutkan sebagai komunikasi immunological maternal 
(Pedersen et al. 2017). Peran resipien dalam menyediakan hormone progesterone sangat penting untuk kelangsungan hidup embrio sejak perkembangan awal sampai lahir atau sebaliknya melakukan penolakan kehadiran embrio (Fazelli \& Holt 2016). Dam effect merupakan pengaruh induk yang berbeda dengan genetik yang diturunkan langsung (direct effect) (Pedersen et al. 2017). Perbedaan dam effect terdapat diantara rumpun induk dan paritas atau umur induk yang berbeda terhadap berat lahir anak (Prastowo et al. 2018). Pada program TE, embrio yang ditransfer mungkin berbeda rumpun, ukuran dengan induk resipiennya, sehingga memerlukan adaptasi embrio yang berpengaruh terhadap perkembangan pre- dan pascakelahiran (Kugonza et al. 2013).

Informasi mengenai sapi BB di Indonesia masih sangat sedikit. Suatu penelitian awal dilakukan untuk mengetahui berat lahir dan mortalitas anak sapi BB pra-sapih dari rumpun induk resipien dan ketinggian tempat yang berbeda. Hasil penelitian ini bermanfaat sebagai rekomendasi bagi pengembangan sapi BB di Indonesia.

\section{MATERI DAN METODE}

Penelitian pendahuluan dilakukan di beberapa instansi Kementrian Pertanian yang berada pada ketinggian tempat yang berbeda. Pengumpulan data berasal dari Balai Penelitian Ternak (450-500 m diatas permukaan laut (dpl), Balai Embrio Ternak (BET) Cipelang (700-1000 mdpl), Balai Pembibitan Ternak Unggul (BPTU) Sapi Perah Baturaden (1000-1200 dpl), BPTU Sapi Potong Padang Mangatas (400-500 dpl) dan BPTU Sembawa (<200 mdpl). Pengelompokan ketinggian tempat berdasarkan ketinggian lokasi institusi dimana induk resipien sapi BB diperlihara dari permukaan laut yaitu dataran rendah (<200 mdpl), dataran sedang (200-700 mdpl) dan dataran tinggi (>700 mdpl).

Pada masing-masing instansi, anak sapi BB murni diperoleh dari hasil Transfer Embrio (TE) sapi BB yang diimpor dari Belgia. TE sapi BB menggunakan resipien induk sapi dari rumpun yang berbeda. Kelahiran anak sapi BB murni melalui operasi Caesar dilakukan sesuai standard operasional dengan arahan dari BET atas rekomendasi dari Belgia. Operasi Caesar pada kelahiran anak sapi BB dari induk resipien dilakukan setelah gejala beranak terlihat.

Pemeliharaan induk resipien selama kebuntingan pada semua lingkungan (instansi) mendapatkan perlakuan optimal. Pemberian pakan berupa rumput unggul gajah atau raja yang tersedia antara 30-50 kg tergantung berat badan induk (10\% berat badan). Pada pemeliharan induk di dataran rendah, rumput jenis brachiaria sp tersedia pada padang penggembalaan. Sedangkan pemberian konsentrat dengan kandungan protein 16-18\% sebanyak 5-8 kg (2-3\% berat badan). Air minum tersedia ad libitum.

Pemeliharaan anak sapi BB murni pada dataran sedang dan tinggi pasca kelahiran mendapatkan kolostrum selama seminggu sebanyak 5-7 liter/ekor/hari. Pada dataran rendah, anak sapi menyusu langsung pada induknya setelah pemberian kolostrum selama 3-5 hari. Anak sapi BB mulai diberi pengenalan pakan rumput dan konsentrat pada umur 1 bulan secara bertahap seiiring dengan pengurangan pemberian susu pada anak dengan bertambahnya umur.

Sebanyak 86 anak sapi BB digunakan dalam penelitian ini berasal dari ketinggian tempat yang berbeda dan rumpun induk resipien berbeda. Rumpun induk resipien meliputi sapi Brahman, Peranakan Ongole, Simental, Limosin dan Frisian Holstein (FH). Peubah yang diamati adalah berat lahir dan mortalitas (\%) pra-sapih (umur $<5$ bulan) anak sapi BB. Berat lahir ditimbang pada hari yang sama saat kelahiran. 
Data kelahiran dan kematian anak sapi BB merupakan pool data dari laporan rekapitulasi setiap institusi. Mortalitas anak sapi BB diperoleh dari total jumlah anak sapi BB yang mati selama pra-sapih (umur $<5$ bulan) dari setiap lokasi (instansi) pemeliharaan. Nilai (\%) mortalitas dihitung berdasarkan jumlah anak sapi BB pra-sapih yang mati terhadap total kelahiran anak sapi BB.

Data berat lahir dianalisa dengan model linear menggunakan SAS (2003) dengan sumber keragaman adalah sex anak, ketinggian tempat dan rumpun induk resipien. Model yang digunakan sebagai berikut:

$\mathrm{Y}_{\mathrm{ijklmn}}=\mu+\mathrm{L}_{\mathrm{i}}+\mathrm{S}_{\mathrm{j}}+\mathrm{G}_{\mathrm{k}(\mathrm{i})}+\mathrm{e}_{\mathrm{ijk}(\mathrm{i}) \mathrm{l}}$

dimana;

$\mathrm{Y}_{\mathrm{ijk}(\mathrm{i}) \mathrm{l}}=$ berat lahir

$\mu=$ rataan

$\mathrm{L}_{\mathrm{i}}=$ pengaruh ketinggian tempat taraf ke-i

$\mathrm{S}_{\mathrm{j}}=$ pengaruh sex anak taraf ke-j

$\mathrm{G}_{\mathrm{k}(\mathrm{i})}=$ pengaruh rumpun induk resipien taraf ke-k tersarang pada factor ketinggian tempat taraf ke-i

$\mathrm{e}_{\mathrm{ijk}(\mathrm{i}) \mathrm{l}}=$ residual error

Nilai P-diff $(\alpha=0,05)$ digunakan untuk menguji perbedaan signifikansi antara ketinggian tempat, rumpun induk resipien dan sex anak. Data mortalitas dianalisa menggunakan uji chi-square $(\alpha=0,05)$.

\section{HASIL DAN PEMBAHASAN}

Tabel 1 menampilkan rangkuman data berat lahir dan survivabilitas anak sapi BB yang diperoleh dari 5 lokasi penelitian. Rataan berat lahir anak sapi BB murni dalam penelitian ini tidak berbeda dari penelitian yang dilaporkan sebelumnya yaitu berkisar 49,2-50 kg (Kolkman et al. 2010; Fiems \& Ampe 2014). Kemiripan rataan berat badan anak sapi BB dalam penelitian ini dengan literatur disebabkan oleh kemungkinan embrio beku sapi BB murni berasal dari negara atau lokasi yang sama sehingga peluang kesamaan keturunan dari tetua sapi BB yang sama atau berdekatan. Koefisien variasi berat lahir dalam penelitian ini 13,72\% yang dipengaruhi oleh adanya perbedaan rumpun induk resipien, lingkungan pemeliharaan dan sex anak sebagai sumber keragaman.

Tabel 1. Rangkuman data berat lahir dan survivabilitas anak sapi Belgian Blue

\begin{tabular}{lc}
\hline \hline & Berat lahir $(\mathrm{kg})$ \\
\hline Minimum & 35,00 \\
Maksimum & 67,50 \\
Rataan & 50,25 \\
Standard deviasi & 7,28 \\
Koefisien variasi (\%) & 13,72 \\
\hline
\end{tabular}

\section{Berat lahir}

Berat lahir pada ternak ruminansia termasuk salah satu sifat yang memiliki nilai ekonomi yang tinggi karena berkorelasi dengan pertumbuhan dan daya hidup anak (Sharma et al. 2012). Berat lahir dapat mencerminkan potensi genetik sifat pertumbuhan, sehingga digunakan dalam seleksi untuk sifat pertumbuhan. Pengaruh induk atau dam effect sangat besar terhadap berat lahir anak terutama sejak masih embrio berkaitan 
dengan kemampuan induk menyediakan lingkungan yang mendukung pertumbuhan anak dalam uterus sampai masa sapih (Kamal et al. 2013).

Tabel 2 menyajikan Least Square Means (LSM) dan standard error (SE) dan $p$ value dari berat lahir anak sapi BB. Berat lahir anak sapi BB dipengaruhi $(\mathrm{P}<0,05)$ oleh rumpun induk resipien. Anak sapi BB yang dilahirkan dari induk resipien rumpun $\mathrm{FH}$ (sapi perah) memiliki berat tertinggi $(\mathrm{P}<0,05)$ yaitu 55,56 kg. Berat lahir terendah $(\mathrm{P}<0,05)$ berasal dari rumpun induk resipien sapi PO (39,58 kg) dan Brahman $(44,44 \mathrm{~kg})$. Sedangkan induk resipien rumun Limosine dan Simental memiliki berat lahir sedang diantara FH dan PO serta Brahman $(\mathrm{P}<0,05)$, namun berat lahir keduanya sama $(\mathrm{P}>0,05)$ yaitu masing-masing $50,53 \mathrm{~kg}$ dan $50,85 \mathrm{~kg}$.

Kesamaan berat lahir antara resipien induk Brahman dan PO disebabkan kedua rumpun tersebut tidak berbeda yaitu termasuk rumpun Bos indicus. Demikian pula antara resipien induk Simental dan Limosin keduanya tergolong dalam Bos taurus tipe sapi potong (pedaging). Sementara berat lahir anak sapi BB tertinggi berasal dari sapi FH yang termasuk dalam Bos taurus tipe perah. Kugonza et al. (2013) menyebutkan perbedaan lingkungan maternal antara induk resipien tipe perah dan tipe potong pada TE. Pada induk resipien sapi potong dengan kemampuan produksi susu rendah dan lebih panjang dewasa ukuran tubuh seperti sapi Bos indicus, embrio tidak dapat mengekspresikan potensi genetiknya secara maksimal. Dalam penelitian ini, embrio sapi BB tidak dapat menghasilkan berat lahir sesuai dengan potensi genetiknya pada resipien induk sapi PO dan Brahman.

Tabel 2. Least square mean, standrad error dan P-value berat lahir sapi Belgian Blue (kg)

\begin{tabular}{llll}
\hline \hline Sumber keragaman & $\mathrm{N}$ & LSM & P-value \\
\hline Ketinggian tempat & & & 0,0001 \\
Dataran rendah & 18 & $43,09 \pm 1,46^{\mathrm{a}}$ & \\
Dataran sedang & 25 & $51,11 \pm 0,92^{\mathrm{b}}$ & \\
Dataran tinggi & 43 & $54,18 \pm 1,29^{\mathrm{b}}$ & \\
Rumpun induk & & & 0,0001 \\
Brahman & 13 & $44,44 \pm 1,68^{\mathrm{a}}$ & \\
Peranakan Ongole & 5 & $40,58 \pm 2,71^{\mathrm{a}}$ & \\
Simental & 29 & $50,53 \pm 1,12^{\mathrm{b}}$ & \\
Limosin & 14 & $50,85 \pm 1,62^{\mathrm{b}}$ & \\
Friesian Holstein & 25 & $55,56 \pm 1,21^{\mathrm{c}}$ & \\
Sex anak & & & 0,3864 \\
Jantan & 46 & $50,86 \pm 1,15$ & \\
Betina & 40 & $49,55 \pm 1,04$ & \\
\hline
\end{tabular}

${ }^{\mathrm{abc}}$ superskrip pada kolom yang sama menunjukkan perbedaan nyata $(\mathrm{P}<0,05)$

Pengaruh maternal (maternal effect) resipien dalam pertumbuhan fetus sampai lahir dipengaruhi oleh genotip dibandingkan paternal genotypenya (Nogueira et al. 2012). Sharma et al. (2012) menyebutkan lingkungan uterus merupakan regulator pada berat lahir dan dimensi ukuran tubuh anak yang dipengaruh oleh rumpun induk resipien. Robles \& Chavatte-Palmer (2017 mengatakan ukuran dan besar tubuh induk resipien 
mempengaruhi ukuran dan pertumbuhan embrio sampai anak pasca lahir. Dalam penelitian ini lingkungan uterus terbaik adalah induk resipien sapi FH yang menghasilkan berat lahir tertinggi.

Selanjutnya Nogueira et al. (2012) menjelaskan adanya perbedaan performa reproduksi antara Bos taurus dan Bos indicus, dimana dibuktikan dalam penelitiannya Bos indicus (Nellore) lebih efisien dibandingkan Bos taurus (Angus) di Brasil. Peneliti lain mengungkapkan sebaliknya Bos taurus seperti sapi FH lebih direkomendasikan sebagai induk resipien dalam program TE disebabkan tergolong sebagai ternak tipe perah yang memiliki fertilitas, mothering ability superior (Hansen et al. 2014). Selanjutnya Kamal et al. (2013) mengatakan perbedaan sapi tipe daging dan potong pada sifat mothering ability sejak embrio sampai lahir, dimana tipe perah lebih tinggi.

Ketinggian tempat berpengaruh nyata terhadap berat lahir $(\mathrm{P}<0,05)$. Berat lahir anak BB terendah $(\mathrm{P}<0,05)$ terdapat pada pemeliharaan di lingkungan dataran rendah $(43,09$ $\mathrm{kg}$ ). Berat lahir sapi BB murni yang dipelihara pada dataran sedang (51,11 kg) dan dataran tinggi $(54,18 \mathrm{~kg})$ tidak berbeda. Perbedaan berat lahir sapi BB antara dataran rendah dan dataran sedang dan tinggi kemungkinan disebabkan perbedaan jenis pakan (hijauan dan konsentrat) yang diberikan sehingga mempengaruhi kualitas dan kuantitas asupan induk resipien yang berpengaruh langsung terhadap pertumbuhan fetus dalam uterus. Robles \& Chavatte-Palmer (2017) mengatakan kuantitas dan kualitas asupan nutrisi dan status metabolisme induk resipien mempengaruhi ukuran dan pertumbuhan embrio sampai anak pasca lahir.

Penelitian Telupere \& Katipana (2014) melaporkan adanya pengaruh ketinggian tempat dan sistem pemeliharaan terhadap performa produktivitas induk termasuk berat lahir. Sistem pemeliharaan dan ketinggian tempat dilaporkan juga berkaitan dengan ketersediaan kuantitas dan kualitas pakan. Pada dataran rendah ketersediaan pakan hijauan berkualitas dalam pelitian ini kemungkinan lebih rendah dibandingkan dataran tiggi. Sistem pemberian pakan yang tidak sesuai kuantitas dan kualitas dengan kebutuhan mempengaruhi kebuntingan induk (Robles \& Chavatte-Palmer 2017).

Interaksi antara genotip dan ketinggian tempat dihubungkan dengan ZTC rumpun ternak spesifik lokasi/zona, dimana genotip tertentu sesuai dipelihara pada zona tertentu. Suretno et al. (2017) menyebutkan bahwa adanya interaksi antara kesesuaian ketinggian tempat dan genotip sapi terhadap performa berat badan sapi berkaitan dengan adaptasi terhadap suhu udara panas. Bos taurus menampilkan produktivitas lebih tinggi pada daerah dataran sedang sampai tinggi disebabkan suhu udara lebih rendah (sejuk-dingin) dibandingkan Bos indicus lebih tahan terhadap suhu udara panas dan cekaman panas (Kerr 2015).

Sex anak tidak berpengaruh $(\mathrm{P}>0,05)$ terhadap berat lahir. Berat lahir anak sapi BB jantan $(50,86 \mathrm{~kg})$ tidak berbeda $(\mathrm{P}>0,05)$ dengan anak betina $(49,55 \mathrm{~kg})$. Kolkman et al. (2010) dalam penelitiannya di Belgia juga menyebutkan tidak adanya pengaruh sex anak terhadap berat lahir anak sapi BB, dimana berat lahir anak sapi BB betina dan jantan masing-masing 49,0 kg dan 49,4 kg. Demikian pula Fiems \& Ampe (2014) melaporkan berat lahir anak sapi BB betina dan jantan hampir sama yaitu 51,6 dan 48,4 kg. Berat lahir anak sapi BB jantan dan betina dalam penelitian ini tidak berbeda dengan penelitian dalam literatur lainnya disebabkan anak sapi BB dalam penelitian berasal dari embrio beku yang diimpor dari Belgia, meskipun anak sapi BB dalam literatur berasal dari kawin alam. 


\section{Mortalitas}

Lingkungan eksternal sangat mempengaruhi fisiologi ternak secara langsung ataupun tidak langsung. Setiap spesies ternak mempunyai batasan tertentu (zones of thermal comfort = ZTC) dimana ternak merasa nyaman dengan batas minimum dan maksimum cahaya (radiasi) matahari, suhu dan kelembaban udara yang sesuai dengan fisiologi ternak (Ratnakaran et al. 2017). Apabila ternak ditempatkan pada lingkungan yang tidak sesuai dengan ZTC nya menyebabkan terganggunya fungsi fisiologi ternak yang dapat menurunkan produktivitasnya.

Tabel 3 menampilkan mortalitas anak sapi BB pada ketinggian lingkungan yang berbeda. Mortalitas dipengaruhi $(\mathrm{P}<0,05)$ oleh ketinggian tempat dimana anak sapi $\mathrm{BB}$ dipelihara. Jumlah kelahiran pada masing-masing dataran rendah, sedang dan tinggi sangat bervariasi disebabkan oleh perbedaan tingkat keberhasilan transfer embrio sapi BB. Anak sapi BB yang dipelihara di dataran rendah memiliki kemampuan daya hidup terendah ditandai dengan mortalitas tertinggi $(\mathrm{P}<0,05)$. Sementara pada lingkungan dataran sedang menampilkan survivabilitas tertinggi. Kematian anak sapi BB dalam penelitian ini disebabkan oleh pneumonia, diare, kejang dan demam tinggi. Kolkman et al. (2012) melaporkan tingkat kematian sapi BB sampai umur pra-sapih sebesar 12,5\% dimana umumnya disebabkan oleh infeksi penyakit seperti pneumonia, diare dan kebersihan lingkungan.

Beberapa literatur melaporkan kelemahan ternak DM antara lain tingkat stres lebih tinggi atau lebih peka terhadap tekanan akibat pengaruh lingkungan sehingga menurunkan daya hidup dibandingkan ternak non-DM (Chen et al. 2012). Menurut Fiems (2012), ternak DM memiliki organ-organ tubuh (seperti hati dan jantung, paru-paru), saluran pencernaan yang lebih kecil sehingga pertukaran oksigen lebih sedikit dan kapasitas konsumsi pakan juga lebih rendah, resistensi stress yang lebih rendah. Anak sapi BB dilaporkan mati karena mudah mengalami stress (Bouyer et al. 2014). Sementara Cieploch et al. (2017) melaporkan kelemahan sapi DM banyak menderita sindrom klinis (penyakit pernapasan, urolithiasis, alveolar hypoxia, hypoxemia). Dalam penelitian ini tingkat kematian anak sapi BB pada dataran rendah tertinggi disebabkan kemungkinan oleh resistensi stres cekaman panas sangat rendah.

Pengaruh ketinggian tempat terhadap mortalitas pra-sapih anak sapi yang disebabkan oleh perbedaan suhu udara, kelembaban, radiasi matahari, kecepatan angin dan curah hujan juga dilaporkan oleh Neary et al. (2013). Penelitian yang dilakukan oleh Pribadi et al. (2015) melaporkan bahwa mortalitas baik sapi lokal dan persilangan tertinggi terjadi pada lingkungan dataran rendah disebabkan oleh suhu udara lebih tinggi dibandingkan pada dataran sedang atau tinggi. Dalam penelitian ini anak sapi menunjukkan gerakan napas yang lebih cepat dibandingkan anak sapi lain meskipun informasi datanya belum tersedia, sehingga perlu dilakukan penelitian lanjutan untuk mengamati fisiologi yang berpengaruh terhadap tingkat cekaman.

Faktor lingkungan merupakan faktor penentu kondisi ternak saat hipotermia (cekaman dingin), atau hipertermia (cekaman panas) atau nyaman (comfort zone). Pada daerah dataran rendah dimana melampau ZTC ternak mengalami cekaman panas dan sebaliknya. Kondisi ternak dalam cekaman panas atau dingin menyebabkan stress fisiologi (Kerr 2015). Tingginya kematian anak sapi BB dalam penelitian ini kemungkinan salah satunya disebabkan oleh cekaman tropis terutama pada dataran rendah. Sedangkan pada dataran tinggi disebabkan oleh menurunnya tekanan udara. 
Tabel 3. Mortalitas (5) anak sapi Belgian Blue

\begin{tabular}{lccc}
\hline \hline \multirow{2}{*}{ Ketinggian lingkungan } & Total kelahiran (ekor) & \multicolumn{2}{c}{ Mortalitas } \\
\cline { 3 - 4 } & & $\mathrm{N}(\mathrm{ekor})$ & $\%$ \\
\hline Dataran rendah & 18 & 11 & $61,1^{\mathrm{a}}$ \\
Dataran sedang & 45 & 10 & $22,3^{\mathrm{b}}$ \\
Dataran tinggi & 31 & 13 & $41,9^{\mathrm{c}}$ \\
\hline abc superskrip pada kolom yang sama menunjukkan perbedaan nyata $(\mathrm{P}<0,05)$ &
\end{tabular}

\section{KESIMPULAN}

Ketinggian lingkungan dan rumpun induk resipien berpengaruh terhadap berat lahir anak sapi BB dan mortalitas. Berat lahir anak sapi BB tertinggi pada dataran tinggi. Rumpun induk resipien FH menghasilkan berat lahir tertinggi. Rumpun FH direkomendasikan sebagai induk resipien dalam program TE sapi BB. Pemeliharaan sapi BB sebaiknya pada lingkungan dataran sedang sampai tinggi. Penelitian lanjutan berkaitan dengan adaptasi dan fisiologi sapi BB perlu dilakukan.

\section{UCAPAN TERIMA KASIH}

Ucapan terima kasih kami sampaikan kepada BPTU-HMT Sapi Perah Baturaden, BPTU-HMT Sapi Potong Padang Mangatas, BPTU-HMT Sembawa dan BET Cipelang atas segala bantuan tenaga, data, dan fasilitas sehingga penelitian ini berjalan dengan baik.

\section{DAFTAR PUSTAKA}

Batubara A. 2017. Ekspresi gen myostatin dan aplikasinya pada program pemuliaan kambing. Wartazoa. 27:89-94.

Bittante GA, Cecchinato A, Tagliapietra F, Verdiglione R, Simonetto A and Schiavo S. 2018. Crossbred young bulls and heifers sired by double-muscled Piemontese or Belgian Blue bulls exhibit different effects of sexual dimorphism on fattening performance and muscularity but not on meat quality traits. Meat Science. 137:24-33.

Bouyer C, Forestier L, Renand G, Oulmouden A. 2014. Deep intronic, mutation and pseudo exon activation as a novel muscular hypertrophy modifier in cattle. PLoS One. 9:1-5.

Chen HQ, Qin V, Zhu YJ, Pan ZT, Xie YN, Jiao MH, Chen GW, Chen H, Chu MX. 2012. The polymorphisms of goat THRSP gene associated with ecological factors in Chinese indigenous goat breeds with different lipogenesis ability. Asian J Anim Vet Adv. 7:802811.

Ciepłoch A, Rutkowska K, Oprządek J, Poławska E. 2017. Genetic disorders in beef cattle: A review. Genes Genom. 39:461-471

[Ditjen PKH] Direktorat Jenderal Peternakaan dan Kesehatan Hewan. 2017. Tingkatkan produksi daging sapi di Indonesia, Ditjen PKH Kementan kembangkan sapi Belgian Blue. [Internet]. [cited 2 April 2019]. Available from: http://ditjenpkh.pertanian.go.id/tingkatkan-produksi-daging-sapi-di-indonesia-ditjenpkh-kementan-kembangkan-sapi-belgian-blue. 
Fazelli A, Holt WV. 2016. Cross talk during the periconception period. Theriogenology. 86:438-442.

Fiems LO. 2012. Double muscling in cattle: Genes, husbandry, carcasses and meat. Animals. 2:472-506.

Fiems LO, Ampe B. 2014. Importance of dam BW change and calf birth weight in doublemuscled Belgian Blue cattle and its relationship with parity and calving interval. Animal. 9:94-103.

Hansen PJ, Denicol AC, Dobbs KB. 2014. Maternal embryokines that regulate development of the bovine preimplantation embryo. Turkish J Vet Anim Sci. 38:589-598.

Kamal MM, Eetvelde VM, Depreester E, Hostens M, Vandaele L, Opsomer G. 2013. Age at calving in heifers and level of milk production during gestation in cows are associated with the birth size of Holstein calves. J Dairy Sci. 97:5448-5458.

Kerr S. 2015. Livestock heat stress: Recognition, response, and prevention. WSU Northwest Regional Livestock and Dairy Extension Specialist. FS157E. Pp10. [Internet]. [accessed 2 April 2019]. Available from: http://hdl.handle.net/2376/5277.

Kolkman I, Opsome G, Aerts S, Hoflack G, Laevens H, Lips D. 2010. Analysis of body measurements of newborn purebred Belgian Blue calves. Animal. 4:661-671.

Kolkman I, Hoflack G, Aerts S, Laevens H, Lips D, Opsomer, G. 2012. Pelvic dimensions in phenotypically double-muscled Belgian blue cows. Reprod Domest Anim. 47:365-371.

Kugonza DR, Kayitesi A, Semahoro F, Ingabire D, Manzi M, Hirwa CA, Gahakwa D. 2013. Factors affecting suitability of surrogate dams for embryo transfer in cattle. J Anim Sci Adv. 3:203-210.

Mota RR, Mayeres P, Bastin C, Glorieux G, Bertozzi C, Vanderick S, Hammami H, Colinet F G, Gengler N. 2017 Genetic evaluation for birth and conformation traits in dual-purpose Belgian Blue cattle using a mixed inheritance model. J Anim Sci. 95:4288-4299.

Neary JM, Gould DH, Garry FB, Knight AP, Dargatz DA, Holt TN. 2013. An investigation into beef calf mortality on 5 high-altitude ranches that selected sires with low pulmonary arterial pressures for over 20 years. J Vet Diagn Invest. 25:210-218.

Nogueira E, Cardoso GS, Heitor Romero Marques Jr HR, Dias AM. 2012. Effect of breed and corpus luteum on pregnancy rate of bovine embryo recipients. R Bras Zootec. 41:21292133.

Pedersen HS, Mazzoni G, Stroebech L, Kadarmideen HN, Hyttel P, Callesen H. 2017. Basic and practical aspects of pregnancy establishment in cattle. Anim Reprod. 14:581-588.

Pribadi LW, Maylinda S, Nasich M, Suyadi S. 2015. Reproductive efficiency of Bali cattle and it's crosses with Simmental breed in the lowland and highland areas of West Nusa Tenggara Province, Indonesia. Livest Res Rur Dev. 27.

Prastowo S, Nugroho T, Nurhidayati A, Widyas N. 2018. Konfirmasi dam effect pada sifat berat lahir silangan kambing Boer. Jurnal Ilmu-Ilmu Pertanian. 2.

Ratnakaran AP, Sejian V, Jose SV, Vaswani S, Bagath M, Krishnan G, Beena V, Devi PI, Varma G, Bhatta R. 2017. Behavioral responses to livestock adaptation to heat stress challenges. Asian J Anim Sci. 11:1-13.

Robles M, Chavatte-Palmer P. 2017. Does maternal size, nutrition and metabolic status affect offspring production traits in domestic species?. Anim Reprod. 14:528-537.

SAS Institute Inc. 2003. SAS/STAT User's Guide: Version 6. SAS Institute Inc. Cary, NC. 
Sevane N, Nute G, Sanudo C, Cortes O, Canon J, Williams J, Dunner S. 2014. Muscle lipid composition in bulls from 15 European breeds. Livest Sci. 160:1-11.

Sharma RK, Blair HT, Jenkinson CMC, Kenyon PR, Cockrem JF, Parkinson TJ. 2012. Uterine environment as a regulator of birth weight and body dimensions of newborn lambs. J Anim Sci. 90:1338-1348.

Suretno AD, Purwanto BP, Priyanto R, Supriyatna I. 2017. Evaluasi kesesuaian lingkungan berdasarkan penampilan produksi empat bangsa sapi pada ketinggian berbeda di Provinsi Lampung. Jurnal Veteriner. 18:478-486.

Suyadi S, Nugroho H. 2014 Analysis of reproductive efficiency in Peranakan Ongole (PO) and its crosses with Limousin (Limpo) cattle in East Java, Indonesia. In: Subandriyo, Kusmartono, Kurnianto KASE, Purnomoadi A, Sodiq A, Wiryawan KG, Darodjah S, Inounu I, Darmono, Priyanti A, Wynn P, Han JL, Tay-Hsu J, Idrus Z, editors. Proceedings of The 16th Asia Australia Animal Production. Yogyakarta (Indonesia): Universitas Gadjah Mada.

Telupere FMS, Katipana NGF. 2014. Pengaruh ketinggian tempat dan sistem pemeliharaan terhadap korelasi genetik bobot lahir dengan bobot dewasa sapi Bali. J Nukleus Peternakan. 1:1-6.

Widyas N, Prastowo S, Widi TSM, Budisatria IGS. 2018. Precaution in introducing doublemuscled exotic breeds into Indonesian cattle population. Current Innovation and Implementation of Modern Technology in Food and Sustainable Agriculture. IOP Conference Series: Earth and Environmental Science. 207: 12-22. [Internet]. [cited 2 April 2019]. Available from: https://iopscience.iop.org/article/10.1088/17551315/207/1/012022/pdf. 